\title{
Other Sales and Related Workers
}

National Cancer Institute

\section{Source}

National Cancer Institute. Other Sales and Related Workers. NCI Thesaurus. Code C122555.

Sales and related workers not specifically identified elsewhere. 